\title{
Energy Planning Considering the Policy Dimension Seeking for Sustainable Development
}

\author{
Martim Debs Galvão*, Luis Natal Rossi, Andre Luiz Veiga Gimenes, Miguel Edgar Morales Udaeta \\ Energy Group of the Department of Energy and Electrical Automation Engineering of the Polytechnic School, University of São \\ Paulo, São Paulo, Brazil \\ Email: *martimdg@gmail.com
}

How to cite this paper: Galvão, M.D., Rossi, L.N., Gimenes, A.L.V. and Udaeta, M.E.M. (2018) Energy Planning Considering the Policy Dimension Seeking for Sustainable Development. Energy and Power Engineering, 10, 253-278.

https://doi.org/10.4236/epe.2018.106017

Received: March 1, 2018

Accepted: June 12, 2018

Published: June 15, 2018

Copyright $\odot 2018$ by authors and Scientific Research Publishing Inc. This work is licensed under the Creative Commons Attribution International License (CC BY 4.0).

http://creativecommons.org/licenses/by/4.0/

(c) (i) Open Access

\begin{abstract}
The objective of this work is to analyze the intrinsic aspects for policy dimension inside the energy planning and energy long term sustainability. In that sense, the methodology intends to take the Brazilian example as a case study and offer a somewhat unorthodox perspective on the subject of State energy planning. This matter is, beyond a purely technical question or a problem for the field of exact sciences, a point of primary interest to the field of social and human sciences. More the backbone methodology in this research is the Integrated Energy-Resources Planning (IRP), chosen for its ability to integrate both the supply and demand perspectives in the discussions about energy planning [1] [2]. A historical perspective is a guideline to approach issue: starting at the early Twentieth century, this study covers the major landmarks of the country energy concern to the present day; particularly noteworthy are the implications of the realpolitik-that is, the elements in politics that are developed within the institutional frameworks, such as governmental plans and decisions. As a result, it presents a complex picture, which we try to understand from the perspective of supply and demand integration. The originality of the study lies in the refusal to accept fallacious technical statements, as we consider the issue primarily a human and social problem, but considering the validity of technical statements that are correct.
\end{abstract}

\section{Keywords}

Planning, Public Planning, Energetic Planning, Political Dimension, Resources Integrated Planning

\section{Introduction to the Political Dimension and Power Sector}

The organization and the nature of all processes of transforming electric power 
into work, considering its several models, have been traditionally reviewed and reworked according to the debate around human cultural production, moving forward towards setting up certain assumptions. The so-called generation of electricity, mainly, had their grounds modified over time. Initially, dictated exclusively by seeking a higher diversity of energetic sources subject to cultural treatment, such modifications have extended, along the way and the development of ideas, towards the writing of reviews about the necessities of supplies, that is, about the nature, the working, and, mostly, the reasons of the demand.

Hence, the present work addresses the Political Dimension the human relations that guide the formation of structures and systems, taking as specific object of study the history of the electric power sector in Republican Brazil, that is, as of the last decade of the XIX Century.

Firstly, an explanation is made necessary concerning the nature of the human relations that offered to work within the scope of this analysis. The dimension approached is that of politics, understood as the dispute of ideas and spaces, mainly, decision-making spaces. What seemed to be a good definition was presented by the former president of Uruguay, José Mujica, in 2013, on the occasion of his speech at the 68th General Assembly (UNO): "La política, eterna madre del acontecer humano" (politics, eternal mother of human events), by highlighting how its conception has been stolen by the vilifying understanding of the mere governmental disputes [3].

Therefore, as of that point the referred observations will be written in the following way:

Political Dimension: The use of capitalized initials is justified since it is intended, formerly, to name relevant concepts through which this analysis is developed, and, afterwards, to be explicitly inserted within the scope of the electric power sector planning treatment according to the research group's definition of PIRnaUSP, GEPEA (Electric Power Group of the Department of Electric Power Engineering and Electric Automation of the School of Engineering, University of São Paulo). Consequently, the three other dimensions considered by the group are taken on as knowledge, social, environmental, and technical-economical. This, together with the consideration of the world of demand beyond that of supply in an equivalent way, is the basis of the application of the IRP-integrated resources planning methodology by the group. The abbreviation PIRnaUSP means Integrated Planning of Electrical Power Resources, being a work methodology or tool of planning that seeks to integrate the supply \& demand world into their considerations, equally. The integrated planning originated in the USA known as IRP (Integrated Resource Planning). More about this can be found in [1] and [2].

Through the historical analysis, it is hoped to add up a fundamental component into the understanding, and, mainly, into the Political Dimension approach.

The main role, when it comes to energetic development and policy, belongs to 
the government, institutionally speaking, and, as a matter of fact, the most specific objective is the contribution towards formulating an approach model for the analysis of the Political Dimension, the electric power as a whole, and the planning of the Brazilian electric power sector, specifically.

Because of its incisiveness, carrying out a work by means of electric power seizure consists in a field of intellectual reflection which must be specially oriented towards a debatable criticism, inasmuch as it is structurally regarding the collectivity, both in its productive operation, that is, the production system, and the everyday life of the corporate mass.

The electric power strategic dimension is evidenced both in its most general meaning, from the mere manipulation of the available resources to transform it into work (of several forms along History), and up to its most particular or applied meaning, represented by the mastery of the cutting-edge techniques and technologies.

The strategic character of the issue gains even more determinant incidence when it comes to societies widely dictated by productivity and efficiency indexes; therefore, competitiveness.

In Brazil, since 1934, when the now extinct Código de Águas (approximate translation, Code of Waters) was enacted, within the scope of policies promoted by the government of Getúlio Vargas, the issue of managing the country's natural resources, their possession and utilization, as well as their commercial use, has been object of intense debate and public dispute. More specifically, the electric power case is spotlighted because it is strategically inserted into the biggest project of the 1930 getulist revolution: the industrializing modernization of the Brazilian productive structures and society. The general context of the referred policy, especially as of the 1937 Estado Novo (approximate translation, The New State), revolved around the structuration of a central National State, capable of self-determination assertion, in order to be ready to take over the role of the nation's planning center; the restructuration of the federal institution imbued with the capacity of self-determination assertion was fundamental point. Thus, the national resource possession issue was ranked as top importance order, being the devices about those concerning the possibilities of exploring electric power generation even more significant, so that the national territory waters became the dispute center, as one can symptomatically see when observing the own name of the legal subject, Código de Águas (Code of Waters).

Therefore, through the assessment of the historic narrative in the light of the political theory and the analysis of the Political Dimension, one could explain the question of the structural planning or not of the sector, especially as the planning models and the implementation of public policies in the electric power area are concerned. Thus, the assessment over the historically developed processes, their crises and their successes still play the clarifying role of the understanding of these processes on their decision-making act, eliciting the motivations and interests that will be able to evidence specific positions, politically speaking, contributing to the understanding of the moment in which the sector is found today. 
On observing the narrative, it is inferred that the nervous center of the whole process was the dispute around the treatment prerogatives of the country's sector planning. The motor of this history really lied on the set of objectives defined as the political guiding of the deployment and development of the electric power sector in Brazil. In this sense, it is stated that the history motor here had a symptomatic imitative characteristic of the XX Century's historical deployment and narratives within the so-called occidental world, having as their liners exactly those observed along the debates and disputes of political theory and of ideologies themselves. This is because it could not be otherwise, since the Brazilian specific case issue would be inserted, in an almost caricatural way, into the development of the global narrative with the birth of an Estado Novo project which was, above all, a political phenomenon determined by the debate itself, manager of the history. In the context of the recent independence of the country (1822) and in the even most recent Declaration of the Republic (1889), the big dispute that moved the political and economic structures was spinning by the rhythm of the dispute of planning models that, on their turn, represented, almost materially, nation project ideas, and, specifically, nation management.

\section{Relevant Milestones in the Power Sector}

\subsection{National Electric Matrix within the Period Prior to 1934}

During the Old Republic (1889-1930), also known as the República do Café com Leite (appr. trans., the Coffee with Milk Republic), with the country's economy being basically of agricultural-export nature, all the economic and political power was determined by the São Paulo-Minas Gerais axis. Within this context, the national energetic park consisted in isolated thermoelectric systems, with ample exploration of vegetal-originated sources.

However, during the two first decades of the XX Century, an expansionist outbreak was observed with a significant growth in the demand for electric power caused by the development originated from the coffee culture and the expansion of the automobiles in Brazil. Such growth led to the energetic crisis of 1924-25, culminating in the energy rationing that significantly affected the incipient textile industry of São Paulo State.

In the 1920s, foreign money came mainly from the AMFORP (American) and Light (Canadian), which stood out due to the centralization of a big volume of capital invested in the sector of generation, transmission, and distribution, showing off a prominence that factually drew near a monopoly. A serious difficulty arising from this process was the fact that each company brought together its own technological apparatus, resulting in a mosaic of distinct foreign technologies to be employed in the sector (4).

When the New York stock market crashed in 1929, the capitalist world collapsed and shook up the typical concepts of the classical economy theory, by strengthening the idea that Public Power should invest so as to compete with Private Initiative, and, thus, provide the reduction of electric power prices within 
a worldwide trend.

With the Revolution featured by Getúlio Vargas in 1930, deep changes were processed in the Brazilian society. From the viewpoint of the electric power sector, the most relevant fact is unquestionably the enactment of the Código de Aguas in 1934, which regulated the whole exploration of the natural resources in the country [5].

The Brazilian code followed some international trend of creating own legislations to favor the public domain of natural resources, upon the intervention of the State, as a direct result of the 1930 revolutionary movement. The most immediate direction plan consists in a clear and consistent legislation, focused on printing a nationalizing look onto the state policy, withdrawing the right to access consecrated by the 1891 Constitution. Therefore, the mineral richness and waterfalls stopped being incorporated into the private property of the soil ${ }^{1}$.

\subsection{The 1934 Code of Waters (Código de Águas de 1934)}

In 1934, Getúlio Vargas makes the Code of Waters into the institutional assertion and extension of the exploded revolution, establishing that not only the charges, but even the profit rates should be determined by the Public Power, undertaking a regulative character. Nationalization was only to be forecast in case of proven inefficiency. Thus, it was subjectively accorded that the electric power production would be in charge of the State, and its distribution would be in charge of the private initiative, which the two big foreign holdings operating in the market strongly objected to.

The world economic depression, added up to the recent amendment in the Brazilian legislation incorporated into the Code of Waters, caused the exodus of private capital. As power rationing was imminent, there was a great demand for reforming the Code, especially concerning the charges, to which Vargas gave in promptly, facilitating business expansion upon the reduction of the bureaucratic obstacles.

The 1937 Constitution reaffirmed the Revolution in its most incisive bias, which meant that the trend towards the strengthening of the State, to the detriment of the private initiative, would be maintained.

Despite the changes, however, rationing started in 1942. In face of the low investments, the federal government extended the intervention with the sector: as of 1943, the Federal Council for Foreign Trade (CFCE) started elaborating a project called National Plan for Electrification (PNE). The PNE presented a clear regionalist conception, proposing a regulatory action on the part of the State, remaining the possibility of nationalization in case of necessity.

Historically, the Código de Aguas was a true institutional extension of the 1930 Revolution. The demands for reform concerning the "historic cost" of the charges and other liberalizing measures are positioned as counterrevolutionary

${ }^{1}$ Already in 1933, the new government had extinguished the golden-clause and taken on control of the country's electric power charges. 
expression within the process, which played a mitigating role towards the intent on transformations, as far as possible. The Código de Águas was introduced as an institutional paradigm to be pursued, leading and directing the governist trend of taking up the basic productive spaces and presenting the solution of self-financing through the domestic market.

In post-war Brazil (1945 onwards), there were two trends that determined the role public and private agents should play to keep the development started in 1930 on going: interventionist and liberal. The interventionist front defended the monopoly of the State regarding the infrastructure sectors considered strategic, besides participating in areas where private initiative did not show satisfactory performance. The main objective was to suspend external dependences, developing the country's domestic market. The other front, called liberal, preferably chose the merely regulatory state apparatus, opposing to industrializing public policies, favoring the injection of foreign capital and defending the Brazilian agricultural roots.

Regarding the electric sector, these two trends were dealt with by nationalists and the privatization supporters. However, both had to deal with the same questioning about how to reduce cost of care, increase reliability on supply, that is, electric power safety, and widen the attendance service. Ultimately, therefore, the sector demands referred to the intention of democratization of the access to electricity resource.

The regulation imposed by the Código de Águas established a remuneration of $10 \%$ upon the invested capital, as based on the historic cost. Thus, a deadlock prevailed, as the State was not able to take on the services provided by the foreign concession companies as much as these were not able to expand the investments as necessary-since they were not allowed to increase the electric power charges [4].

With Vargas deposed, the 1946 Constitution was elaborated similarly to those of 1934 and 1937, however, less corporatist and nationalist, reaffirming the Código de Águas and anticipating the taxation form based on flat tax.

Nonetheless, as the domestic crisis became worse, Vargas's popularity was determinant for him to return to power in 1951, factually resuming the institutional-political project that he had already designed in the 1937 Estado Novo.

\subsection{The Second Vargas's Government}

The transformations in the electric power sector in post-war Brazil resulted from the national and international general context, as of the 1930s, and from the crisis caused by the New York stock market crash, with the advance of the industrial capital over the commercial capital-which in the Brazilian case can be roughly summarized as the advance of the prominence of industry over coffee monoculture. The North-American government policy known as New Deal, by President Franklin Roosevelt, marked a world trend of strengthening and interventionism of the State within the infrastructure sectors, mostly in those 
so-called developing countries like Brazil. It meant, therefore, a transformation in the State itself, which ceased being a mere social order maintainer to be consolidated as the main national development agent, within a perspective of overrunning bottleneck ${ }^{2}$.

In parallel, the country's growing urbanization together with the expansion of the domestic markets and the average income provided a big increase in electricity demand. From 1940 to 1963, the demand in the Rio-São Paulo axis grew by $13 \%$ per annum, whereas Light installed capacity grew an average of only $6 \%$ per annum [4].

Politically, the return of Getúlio Vargas to the central government was marked by the intensified resumption of the political project introduced in the country in $1930^{3}$.

In the public debate, the idea of a necessary relaxation of the regulating laws, specially pricing, was insisted upon, giving visibility to the expansion of supply. Part of these conclusions had been defined by the Mixed Commission Brazil-USA (CMBEU), officially created on July 19, 1951, and closing its work on July $31,1953$.

On his second step through power, Vargas fostered the creation of state, private, and, mainly, public companies. Simultaneously, he proposed an even bigger centralization of the direction and order of undertakings, as well as the price and fiscal regulation, through the idealization of a federal-national holding, the Eletrobras. In face of difficulties and resistances, and hoping to leverage its consolidation, the creation of Petrobrás, with oil monopoly, was approved in 1953.

Following the centralization trend, in 1953 the Flat Tax upon Electric Power (IUEE), already foreseen in the Constitution since 1946, was created. On a similar movement, in 1954, Eletrobras was finally created.

As an example of this process, one can consider the PNE, which determined that the electric expansion should be in charge of the State, leaving the transmission and distribution of electric power to the private initiative. Thus, the primacy of the state initiative in the electric power sector was definitely established within the institutional structures. It was concluded, therefore, that the supply should antecede and, thus, stimulate the demand for electric power, by elaborating a National Plan for Electrification (PNE), counting on demand forecasts over 10 years.

Materializing through the National Congress in the form of four draft bills, the plan defended the mass participation of the State in the production and transmission of electric power, due mainly to the vast hydroelectric potential still available and to the very high initial inversions of resources, with low capital turnover [4]. The first and second projects regulated the 1945 Constitution, creating the IUEE, approved some days after Vargas's suicide, not without hot ${ }^{2}$ Exemplifying, in France, the participation of public expenses in the GNP went from 14\% in 1913 to $32 \%$ in 1957; in England, from 9\% (1890) to 37\% (1955); whereas in the USA, from 3\% (1880) to 20\% (1965) (DELFIM apud MEDEIROS, 1993).

${ }^{3}$ In his second government, Vargas established the Economic Counseling of the Civil Office of the Republic Presidency as responsible for planning the country [4]. 
debates between privatization supporters and statists-leaving $40 \%$ of the resources to the Union and $60 \%$ to the states, federal district, and cities ${ }^{4}$. The third project, on its turn, was the PNE itself, which unified the frequency into 60 cycles, submitted the expansion of generation to a planning, aiming to increase the installed capacity from $2 \mathrm{GW}$ to $4 \mathrm{GW}$, forecast the creation of an interconnected transmission system, and regulated the mobilization and utilization of the external resources to a flat tax, coordinated by the State ${ }^{5}$. The fourth project created the national holding Eletrobras, which should manage the state industrial undertakings, such as CHESF, organize the national industry of electric material, and execute the Federal Plan for Electrification, making use of the resources of the Federal Fund, formed by the IUEE, temporarily administered by the BNDE (National Bank for Development).

Thus, there are two aspects particularly shown to be relevant in this movement: the oscillating movement of the correlation of power of the social-political body, in a movement apparently commuting between nationalization and privatization, and the solution adopted for the financing problem.

\subsection{The Target Plan in JK's Government}

With the end of Vargas period, marked by his suicide in 1954, Juscelino Kubitschek took office as President of Brazil, whose government also followed the expansionist perspective, and has as its main objective the so-called Target Plan, which set ambitious objectives over five years. The new government restricted the public company's performance outreach as the base industry is concerned, retaking somewhat indirectly the plan elaborated during Vargas's government, however, implementing the notable attempt to conciliate state and foreign investments.

Thus, Kubitschek enabled a significant part of the programs elaborated by the extinct mixed commission Brazil-USA, showing a clear decentralizing movement of the planning process and decision-making action within the administrative scope.

The IUEE began to be part of the charges of the former BNDE. In this sense, an important change was carried out: it consisted, as of 1934, in the first fundamental change of course, and it was the first real expansion of the possibility of using foreign private credit. The BNDE was responsible for financing the expansion of the electric power sector, upholding the credit program of public and private companies upon contribution of capital within favorable conditions to-

4 "The underground campaign of the international groups allied with the national groups. [...] The foreign companies' profits reached up to $500 \%$ per annum [...]. I fought against the pillage of Brazil. I fought against the pillage of the people" [6].

${ }^{5}$ This project was never approved by the Congress, but it remained as a referential mark not only for the debate around the issue, but as the formulation of the other plans that followed - besides consolidating some guidelines towards the future of the sector and setting up the trend of the State domain upon generation and transmission, making investments more difficult for the private initiative, leaving the distribution of electricity for the private sector, because it has a smaller time of investment maturation. 
wards the concession companies, as a political project of the government. Therefore, the state government's commitment was translated by the creation of innumerous state companies connected to the project via BNDE.

In JK's government, the Target Plan begins to delineate the social importance of the political attempt to universalize the access to electric services, with ambitious objectives set up in two categories, with the purpose of getting on with the works already started, reaching 5 GW until 1960; carrying out works not yet started, reaching $8 \mathrm{GW}$ until 1965; and, paradoxically, the plan forecast the necessity of additional investments in order to fulfil the adopted targets, simultaneously with the forecast of drop in the participation of private capitals, mostly foreign. Alike the $1954 \mathrm{PNE}$, it consolidated the trend to separate generation and transmission of electricity to the public sector and the distribution to private companies, such as Light and AMFORP.

The economic model became more delineated as of these definitions, establishing that the State should promote the development leverage, mainly in the infrastructure sectors, whereas the private initiative would be responsible for industrialization, through import substitutions. In the electric sector, the stimulus towards foreign capital would be a lot inferior as compared to other sectors. Following the world trend, the electric sector would cease meaning good business, mainly for the private ones.

Therefore, expanding the autonomy of the regional companies in face of the federal power, even being part of the Vargas project, due to the way it was put into practice, entailed a restructuration of the political-social power correlation ongoing since the 1930 Revolution. The reformulation and substitution of the former Código de Aguas in 1957 was, in part, a result from this rearrangement of political powers. In the new regulation, a higher flexibility towards the readjustment of charges was introduced.

With expansionism as hot topic in the central power ${ }^{6}$, the federal company Central Elétrica de Furnas (Central Electric of Furnas) was created in 1957, with the purpose of exploring the Grande river, once the Southeastern region remained the main energetic challenge, in the Rio-São Paulo axis, and Light had already practically exhausted the electricity-generation hydric potential-including the increase of the installed capacity of the existing plants and promoting the damage of the technical quality of the distributed electricity. Therefore, when the State went on directly into generation, the nationalists' thesis gained force because it had been the model that enabled the execution of works, proving that substituting foreign companies was possible.

However, those in favor of privatization connected to foreign capital realized how the new division of tasks could benefit their interests. With the huge work plans, big amounts of resources would be necessary, favoring the demand for charge increase. It is observed, thus, how the conflict was exceeded, through a circumstantial situation that pleased both sides: it provided the foreign companies with a survival and adjusted to the state model, with technical, managerial,

${ }^{6}$ About this assertion, simply recall the main slogan of JK's government: "to grow fifty years in five". 
and financing empowerment ${ }^{7}$.

In a certain way, it can be said that an agreement was materialized towards the coexistence of the Brazilian State and the national and foreign capitalism, which was outlined as of World War II.

It is observed that the essence of the measures proposed by JK was engaged in making public undertakings effective. In 1960 the Ministry of Mines and Energy was created, incorporating the former National Counsel for Waters and Electric Power and the Division of Waters, with the Ministry of Agriculture, besides the federal companies of the sector.

Therefore, the consecutive autonomy of the state Companies and the changes in the original Project idealized by the 1934 Código de Aguas ended up by creating, at last, the Centrais Elétricas Brasileiras-Eletrobras (Brazilian Electric Plants-Eletrobras).

Therefore, Eletrobras went on to take the role that so far had been played by BNDE, controlling the Federal Fund for Electrification (FFE) and the application portfolio made together with the concession companies. The big national holding of the electric sector was, thus, consolidated, being responsible for the direction and interconnection between several state companies in the country as well as the regulation of those of private initiative, either with national or foreign capital.

Enacted through Act 3.890-A, dated April 25, 1961, the project was made effective also because the possibility of being associated to the electric material industry was withdrawn, preventing, then, the creation of a national qualification centered on this field. However, it was enacted with the original essence intact, being a state company disconnected from the classical public service; a holding; planner and promoter of the electric development, besides being solid and large-sized.

Institutionally, the private company gave way to the public company through the Code, which determined the trend towards nationalization. Thus, Vargas's and JK's governments (1951-1961) expanded the nationalist-intent development, with the strong participation of the State in the economy. Between 1951 and 1955 , the industrial product grew by $8.1 \%$ per annum and $11 \%$ per annum between 1958 and 1961. It is worth pointing out that, despite nationalists, both governments had good receptivity towards the foreign capital, mainly due to the difficulty of focusing the expected speed of national development exclusively on domestic resources.

\subsection{From the1964 Coup to the Consolidation of the Federal Holding}

The 1964 military coup triggered a process of ample reforms of authoritarian trend in the scope of public administration. Accelerating the process of institu${ }^{7}$ However, it was forecast that, inasmuch as it expanded its expertise and capacity of management, the State would leave the generation scope to control the whole productive process of electricity, distribution included. 
tionally making regional means autonomic, the expansion of companies of the State Productive Sector (SPS) was spurred on. The coup process of April 1964 enabled the consolidation of the State model for the electric sector, approximately accordingly to the political project that rhetorically was being designed, in an explicit manner, as of 1945.

Therefore, the consolidation and expansion of Eletrobras took place. The legislation leaves off regulating the relation between Public Power and private sector, and went on representing effectively the ordination of the federal power relation with public companies, dominant, and the others.

Despite the resemblance, the carried-out project brought up outstanding differences in relation to the original "getulist" project, due to the accentuated process of income concentration and social inequality-because of the dismantling of the so-called populist pact or popular nationalist pact, as well as of the paralysis of the "political fizz".

The national economy and the development of infrastructures were built up around the prominence of the State currency, originated from fundamental sources: taken from domestic savings, by means of compulsory tributary charges; and the access to international credit, in a "slow, gradual, and safe" process of State's indebtedness. A deliberated policy of capitalization of the economy was, thus, established through big state companies.

With the clear direction towards gradual nationalization, the country moved on, keeping on and amplifying the reforms initiated by Kubitschek's government, operating some equilibrium between the revolutionary project of the 1930s and the main opposition powers acting since then. Faithful to the safety and development binomial, the legal milestone of the 1964 Coup was the 1967 Constitution, which maintained the sense of expansion and enlargement of the operation spheres of the State in the sector.

Dated November 1964, the Programa de Ação Econômica do Governo-PAEG (Economic Action Program of the Government), encompassing a three-year period, presented markedly-macroeconomic objectives. For the years 1965-1967, it projected growth rates of around $6 \%$ and $7 \%$ per annum, besides stimulating tax credits to the companies' profits reversal, implementation of compulsory capitalization plans on the part of the users of public utility services, and comprehension of the cost deficits of autarchies and societies of mixed economy character. Still in November 1964, it was established by decree that the service cost would be the electricity pricing indicator, putting an end to the dispute between nationalists and privatization supporters, at least temporarily ${ }^{8}$. As a result, the charges increased an average of 60\% above inflation between 1964 and 1967, in a policy said to be "pricing reality", transforming the electric sector into an economically profitable activity, with the remuneration of the investment around $10 \%$ with the assets already re-evaluated [4].

${ }^{8}$ In thesis, the application favored Foreign Companies since they held older goods among their fixed assets, main item of the service cost according to the regulation of the calculation. 
Apart from the pricing increase, the military sought to create extra sources for the sector, manipulating over the IUEE and expanding the amount raised through compulsory loans or Reserva Global de Reversão (RGR) (Reversion Global Reserve) so as to take over the non-state concession companies when their respective concessions expired. Thus, the sector went on counting on financing based on non-budgetary resources, centrally focused on the federal government through Eletrobras, administrator of most of the non-priced resources.

In 1967, an administrative reform was carried out, and that looked forward to the development of state public companies. A strong reduction in the state direct intervention was carried into, despite managing the nationalizing project of the sector. Whilst it encouraged and expected an entrepreneurial rationality of the entities decentralized in the manner of the private sector, it sought to subject it to the policies and projects of the federal government.

Therefore, the State could mobilize the domestic resources through pricing or charging, and the foreign ones through financing loans within the favorable environment of the foreign financing market. Making loans grow mainly as of 1973. However, until 1977, the indebtedness was made within a favorable financing context, providing an accelerated expansion of the capacity installed in Brazil, with reflexes upon practically all the other spheres of the economy, mostly the process of industrialization.

Thus, transitory interferences could be noted, despite presenting strong authoritarian characteristics, typical of the system. The second military government promoted the readjustment of the diagnosis for costs, pointing out that the measures of the former government had transferred volumes from the private sector into the public sector, reducing the available general income and compromising the liquidity of the companies. Therefore, measures to stimulate demand and consume are taken, seeking to mark out the economy within a stable domestic market.

The relaxation of the economy is identified through the facilitation of the capitalist liberal action. When professor and economist Delfim Neto joined the government in 1967, preference was given to the economic growth in detriment of the monetary stability. Thus, in 1968, the Programa Estratégico do GovernoPED (Strategic Program of the Government) was launched, apart from the creation of the Departamento Nacional de Aguas e Energia Elétrica-DNAEE (National Department of Waters and Electric Power), absorbing the attributions of the Conselho Nacional de Aguas e Energia Elétrica-CNAEE (National Council for Waters and Electric Power). The practical result was called the economic miracle, with the strong growth of the GDP and the industrial product.

Therefore, as of 1969 two parallel movements were processed in the sense of further development: the macronational directive centralization, through Eletrobras, and the liberalization of the market issues in the electric power sector, especially as the pricing issue, through the DNAEE, is concerned.

Still in 1967, by presidential decree, the trend to be developed by Eletrobras 
was stressed, and which consisted in privileging the companies within the regional scope in an articulated manner. With administrative and financing reforms concerning the State's operation, the gross fixed capital formation rate was raised from $18.5 \%$ in 1965 to $24.2 \%$ in 1973. In a similar period, the public utility services also registered considerable growth, reaching the mark of $13.2 \%$ per annum.

However, the financing problems of the developments planned by the ambitious works of the Public Power culminated in a new accounting crisis in the sector, in face of which it was decided that loans in foreign currency should be expanded and made at international private banks. Since the 1960s, the development plans insisted on the possibility of attracting private capitals, and the state companies gradually concretized the purchase operations of subsidiaries, mainly of the group AMFORP.

Nonetheless, the increase of the self-financing capacity occurred on the account of the pricing reforms was not enough to avoid the stagnation projection. In 1971 the elevation of the profit maximum rate from $10 \%$ to $12 \%$ with a tax reduction of $17 \%$ down to $6 \%$ on behalf of the concession companies sought to mitigate the companies' shortage situation in the sector.

In 1973, the definite consolidation of the Brazilian federal holding came up with the binational signing of the Tratado de Itaipu (Itaipu Treaty) between Brazil and Paraguay. The regrouping of the companies controlled in four regional concession companies was carried out: Eletronorte, Chesf, Furnas, and Eletrosul. Besides, the Grupos Coordenadores para Operação Interligada-GCOI-(Coordinated Groups for Interconnected Operations) were instituted, in an attempt to centralize the operation, aiming to optimize the generation processes. Concerning the dynamics of the operation and relation of the several companies, the legislative process began to operate as an instrument of regulation of the domestic conflicts for the State apparatus.

The first oil shock in the end of 1973 triggered off disarrangement in the economic system and in the world's electric power market, leading, as a response, to the implementation, in 1974, of the II Plano Nacional de Desenvolvimento (II PND) (II National Plan of Development), which forecast the policy of import substitution of capital assets and basic inputs, financed by growing foreign loans of private capital.

\subsection{The Consolidation of Eletrobras and the 1980s' Crisis}

Already in the Itaipu Project the premises for the electric sector over the 1970s were announced with the clear and explicit option for the big hydroelectric generation developments, confirming the trend noted as of 1934 with the already mentioned Código de Aguas. With the perspective of technical scales roughly higher, added to the limitation of the hydric resources suitable in the Southern, Southeastern, and Mid-Western regions, the Amazon basin in the North of the country was presented as the natural deployment for the project planning. The 
unfolding of these events, despite the consecration of the indebtedness of the sector, consolidated the federal holding Eletrobras as the planning and financing agency of the electric power sector in Brazil.

The reorientation of the investment policy

Over President Geisel's term of office, a new industrialization policy pattern was set up, in which the command of the economic dynamics would be the basic industry and the re-strengthening of the national private capital would be established, when proposing the replacement of the imported oil by the utilization of biomass, electricity, and national mineral coal.

Within this context, and projecting a big increase in the energetic demand, the II PND presented propositions of a big supply expansion in the long term. Plan 90 of 1974 anticipated the integration practice towards the year 1990. Afterwards, with the structuration of the Fundo Nacional de Desenvolvimento (FND) (National Fund for Development), it was encompassed into an institution for financing infrastructure projects.

As the centralization of the powers and decisions within the federal scope was deepened, around SEPLAN, the circumstantial failure to implement the II PND was determined in 1976 with the trend diagnosis of the real deterioration of the charges and prices of the public utility services practiced-observing a rupture in the fundamental paradox with the exacerbated centralization of the tax collection and the strengthening of the FND.

When João Figueiredo took office in 1979, a vast set of measures of maxi exchange devaluation was implemented. A trend to cut down on public investments to get the public accounts back to track was developed, thus, processing the growth refrainment policy. In the long run, the deterioration of the price list system converged to the nationalization of debts, giving up on and abandoning a domestic pricing solution that should assure the possibility for the public companies' self-financing. Therefore, it seems clear how the damage and depreciation process of the public structures were already inevitably wide open, reaching the end of the decade with the first signs of privatization on the sector. As of Plan 95 (aiming the year 1995), the projects definitely achieved the complexity of big interconnected nets, though in an imperfect or even inefficient manner.

As the international interest rates jumped from $7 \%$ to $8 \%$ in 1970 and from $16 \%$ to $18 \%$ in 1980 , the electric power sector was facing a debt of about 10 billion dollars, in values of that time. In addition to that, there was the declaration of Mexican moratorium, which made it even more difficult to access new loans. As a result, there was the reduction of the average remuneration rate for services rendered, which was $12 \%$ per annum from 1975 to 1980 , and which sharply dropped in a short period of time down to 6\% per annum in 1983.

Internationally, the theme around ecology and environment was beginning to gain a prominence bias. The formulations of the concept of Sustainable Development (SD) in 1980 by the Strategy of World Preservation, and, later, in 1987, the Brundtland Our Common Future, by the UN World Committee about En- 
vironment and Development, represented an attempt to conform growth and environmental preservation, consecrating the classical definition of SD as "development that meets the necessities of the present without compromising the capacity of the future generations to meet their own"'. Conceptually, the Sustainable Development, due to its intrinsic subjectivity, acquired several formulations, theoretical and practical, taking as its first connotation the maintenance of the constancy of the natural capital stock. Thus, by its premises, all exhaustion of any natural element is inadmissible, imposing inevitable limits to the use of the non-renewable resources, especially relevant to the question of the energetic planning.

\subsection{The 1980s' Crisis}

The degree of indebtedness in the sector in 1980 was already on the level of $64 \%$, rising to $70 \%$ in four years. In the middle of the decade, the sectorial resources were only sufficient for the debt service. Consequently, due to the self-financing incapacity of the sector, apart from the critical debtor picture, recession took place, configuring what was known as the 1980s' crisis.

Broadly, the model proposed by Vargas in 1930 collapsed, and the new commitment threshold acquired with the private capital, mainly foreign, was established, culminating in the privatization phenomenon that marked out the sector over the 1990s. As the said crisis is concerned, it means mainly the crisis of the reformed model of the 1960s, and, indirectly, of the 1934 original project itself, representing the extinct Código de Águas, which already brought in the main aspects of the State's policies, either as regulator or as direct intervener or even as developer, effectively. The damage on the national matrix was, to a great extent, the result of the impossibility of the plain consolidation of the deferral holding, through Eletrobras, with the supposed assurance of unitary action of the several regional subsidiaries all over the country.

In the core of the impasses, as of the debates around the Código de Aguas, what was always present in a markedly manner was the question referring to pricing and administrative margins of autonomy and/or control.

\subsection{The Power Sector and the Redemocratization}

Under the campaign "diretas ja" (direct elections now!) and with the popular clamor for removing the military from the federal power, Tancredo Neves, from Minas Gerais State, was indirectly elected President. However, due to his death, his vice José Sarney, from Maranhão State and the same party, took office in March 1985. The process of political overture in Brazil is beginning now. However, despite this, it will only be completed with the promulgation of the 1988 Federal Constitution, setting up direct elections in universal suffrage for majoritarian positions, including the Republic Presidency.

${ }^{9}$ The origin of this process can be found in the Clube de Roma, a 1968 Think Tank, which began to show the eminently limited character of growth, populational included, exposing the problem. 
In 1986, the Department of National Treasure is created, with the attribution of administrating the Union assets together with the state companies. This attempt moved towards centralizing the administrative rules and avoiding the political use of the state companies. However, as the ministerial supervision was maintained, little practical result could be observed.

In 1988, when the Constitution was promulgated, the new juridical order removed the resources of the energetic sector, such as the IUEE and the compulsory loans.

\subsection{The Crisis in the State Model and the Liberalization of the Electric Sector}

In 1989, Fernando Collor de Mello becomes the first president elected by direct voting, and takes office in 1990 in the already new democratic period.

With the motto of modernization, Collor presented wide liberal economic conception, whose main infrastructure project was the Programa Nacional de Destatização (PND) (National Privatization Program), which proposed opening towards import, privatizations, industrial and technological modernization, yielding a great deal of currency to the country, even getting the State's debt to recoil.

\section{The Reforms in the Electric Sector}

When sociologist Fernando Henrique Cardoso, from São Paulo State, was elected in 1994, the country began to adopt, even more widely, the recommendations of the Washington Consensus and the International Monetary Fund (IMF), based fundamentally on liberal precepts, economically, in the sense of deregulating the markets and restriction to the role and importance of the State. In the case of the state bureaucracy and infrastructure, it sought to propose the reduction of the size of the State.

In the energetic sector, liberalization meant, mainly, the break-up of the processes of Generation, Transmission, and Distribution (G/T/D), so that no company could hold the domain over the set of operations and projects. Moreover, it was stipulated that competition should be always a search, with the intent to promote efficiency, investments, and low prices. However, the State detained the generation of energy. In general, the reforms as of 1955 were decentralizing, privatizing, and promoters of a competitive market, besides including new commercializing agents.

Although the break-up objectives were not totally accomplished, liberalizing changes in the pricing regulating policies were introduced, as well as the commercialization of energy within a market accessible to the agents.

Another factor worth outlining, since it occurred by denying the institutional tradition, was the expansion of the privatizing program upon financing system from the BNDES. Within a policy that, despite understandable-since the bank is just a foment instrument not only for the private economy but also for promoting public and State policies-it operated in a controversial manner, since it 
used public money to sell, at generous low interest rates, public patrimony to foreign capital.

Within FHC's eight years of government, Brazil collected 78.61 billion dollars from privatizations, and only $53 \%$ of this capital was of foreign origin; 22.33 billion dollars of the total referred to electric power companies. Still, even with the currency generated from privatizations, the loans from international organs, such as IMF, were constant practice during his governments, either as a result of crises in the foreign economic markets, or the government's bad economic management. Thus, the State's foreign debt began to grow again and largely.

The pricings oriented for the final consumer kept on continuously high; on the other hand, investments did not increase at all. With the demand for energy, there appeared a growth trend, too; some dry seasons not especially rigorous for the hydrologic system culminated in a supply crisis and electricity rationing in 2001.

\subsection{The 2001 Crisis in the Electricity Supply}

In a brief conclusion, the situation of the national electric generation matrix reached the exhaustion level due to the lack of related and centralized planning. The pulverization of responsibility and market competition led to the extinction of the centralization formerly represented by Eletrobras and the Ministry.

In April 2001, the storage of the reservoirs of the great hydroelectric dams held a little bit more than $30 \%$ of its capacity. To avoid the perspective of drastic 'black out', in case of a total energy supply rupture, the electricity rationing was adopted between June 2001 and March 22. The target to be met by the program was the economy of $20 \%$ of electric power.

\subsection{Light in the Country}

In 1999, the federal government creates the program Light in the Country, which eventually became a milestone in the State's history of public policies for the Brazilian electric power sector. The objectives of the Program meant basically to increase rural electrification by means of expanding the net or the utilization of renewable sources whenever necessary and advantageous, and it attended to a million consumers up to 2002, with estimates that indicated a billion dollars in investments.

\subsection{The Proinfa}

Already in 2002, the Programa de Incentivo às Fontes Alternativas de Energia Elétrica (PROINFA) (Program for Incentivizing Alternative Sources of Electric Power) was created, establishing that all concession companies should be obliged to universalize the electricity supply to all Brazilian citizens, still without setting up targets to be achieved for that matter. The impact of such determination is highly important as the context of the history of the sector is concerned, since it entailed implications of structural nature on the question of planning, implementation, monitoring, and operation of the system. 
Always searching for solutions to solve generation issues that should diversify and clean the national matrix, with alternative and renewable sources, the development of biodiesel in Brazil was decided upon, focusing on the transformation of castor-oil plant and researches for other possibilities based on the native flora.

In its first phase, the contemplation of $3300 \mathrm{MW}$ up to 2006 was contemplated, divided equally among Eolic and biomass sources and small hydroelectric plants (PCH). Already in the second phase, a target was presented meaning to assure that $15 \%$ of the annual market growth should be met by the Eolic and biomass sources and the PCHs. As a program target, it was stipulated that in 2020 these sources shall be responsible for $10 \%$ of the Brazilian consume.

\subsection{The Reforms Post-2001 Crisis}

In 2002, the country's power sphere underwent a change with the election of metallurgical and syndicalist worker Luís Inácio Lula da Silva, from São Paulo, for President. When Lula took office, the ANEEL (Electric Power National Agency) stipulated, by the 2003 resolution, the universalization targets of access to electric power and transferred the costs of the consumers' new connections to the concession companies.

In 2003, the CDE-Conta de Desenvolvimento Energético (Account for Energetic Development) was created to promote the energetic development. The governmental guideline defines the utilization of the $\mathrm{CDE}$ as priority for universalization, upon favoring low income consumers, also contributing to the intent to universalize the service access.

From the planning viewpoint of the sector, after the 2001 supply crisis, the way to set up the work and investment chronogram was restructured, seeking to give reliability and safety onto the expansion of electricity generation in a conform manner to the demand development. Besides a series of regulating and governist organs and institutions, such as EPE, ANEEL, and ONS, a fundamental resource introduced into the process was the dynamics of electric power auctions, in which the commitment by contract among generators and distributors aimed to assure the effectiveness of investments and projects.

\subsection{Light for Everyone and the Universalization of the Electric Power}

Created to replace the Light in the Country program, the Light for Everyone was launched in 2003 with the explicit objective to anticipate the universalization for 2008. Using CDE reserves and the Reversion Global Reserve, the program is coordinated by the Ministry of Mines and Electric Power together with Eletrobras. With the Light for Everyone program, the intent was to make 667 thousand connections, benefiting 2.8 million people, by implementing it in all states, as of the CGEU-Comitês Gestores Estaduais de Universalização (State Management Committees for Universalization). 


\subsection{The Program to Accelerate Growth-PAC}

The PAC-the growth accelerating program-was announced in the beginning of 2007 with a great national effort so as to accelerate the expansion of the Brazilian economy and production.

As the electric sector is concerned, and considered strategic for the production growth, within the scope of energy generation, investments around $\mathrm{R} \$ 65.9$ billion were forecast for the construction of new plants with the installed power of $12,386 \mathrm{MW}$. In transmission, the project forecast investments around $\mathrm{R} \$ 12.5$ billion to implement $13.826 \mathrm{~km}$ of transmission lines.

The Plangás-Plano de Antecipação na Produção de Gás Natural (Natural Gas Production Anticipation Plan), still within the scope of the PAC-derivate projects, projected $\mathrm{R} \$ 25$ billion in associated gas production projects, and $\mathrm{R} \$ 12.5$ billion in the construction of $4.526 \mathrm{~km}$ of transportation pipelines.

In the refining park, $\mathrm{R} \$ 22.6$ billion were destined to 10 existing refineries with the purpose of modernization, generating environmental gains and elevation of the participation share of the national heavy petroleum processing as the import petroleum substitution.

\section{The Analysis of the Political Dimension into Energy Planning}

Technically, there was not even a specific optimization to be achieved, precisely because the final scope of what is considered optimum shall not be that of technical nature, but political. Therefore, planning in its modern meaning of the process is described as the planning of development flexible strategies. Ultimately, it corresponds to a comparison exercise between two or more alternatives of viability of premises, and its complexity is defined in terms of margin of reserve and reliability, as well as uncertainty and risk.

Objectively, the political element while integrating part of a process that should be recognized as electric planning activity, in its more subjective, abstract, and indirect manner, could be described as inevitable and even constituent of the progress and dynamics of the occurrence of the facts itself, that is, inescapable while participant agent of the process.

Undoubtedly, the perception of the political element as an inevitable component of the decision-making processes is true. However, this does not even necessarily imply that the consideration of its dynamics has been at least recognized within the progress and closure of the results. For such, it is essential that one should work on that matter, initially in the theoretical field, so as the incorporation can be done even theoretically; composing the discursive structure presented as good methodological practice of planning and decision-making.

\subsection{Difficulties}

Considering that the great tool and the methodological instrument of the Political Dimension inclusion into the PIR scope mean precisely the consideration of the agents closely linked to the process, the so-called En-In (Envolvidos e Inte- 
ressados) (Involved and Interested), it was expected that difficulties should be found. It is interesting to point out how, in this case, the difficulties are not of practical or material nature, but, yes, of any kind of inability to effectively include these closely-linked agents into the analysis work. Therefore, it is inescapably concluded that the difficulties of practical and material nature in this case correspond in fact to consequences of deficiencies occurred in moments before planning.

Therefore, the solutions for the difficulties considered specific for the inclusion of the Political Dimension into the PIR scope would be of theoretical nature, with the improvement of the rhetorical and discursive resources that led to an unsatisfactory appreciation and incorporation of the dynamics referring to the En-In inside the supply and demand scope, in an integrated manner.

The PIR must always highlight its acknowledgment that the human factor is inherent in the whole energetic planning, and, therefore, theoretically and practically inaccurate. That's why a reasoned treatment of the key-uncertainties is shown to be more valuable than an exhaustive treatment of all observable uncertainties. When it comes to Political Dimension, these characteristics become even more highlighted.

\section{The Political Dimension and the New Renewable Power Sources Planning}

The Sun is the primordial source. Practically, the whole energy that in a certain way is out there available is directly related to the Sun. In its origin, though. The set of energy that hits the Earth in the form of insolation, deriving from the Sun, would be enough to meet the energetic demand of the whole planet.

Historically, the solar energy was long indirectly used through collecting action: farming, hunting, animal taming, etc. Water and the wind, on the other hand, were systematically adopted to offer necessary energy to carry out tasks.

In Brazil, as of the XX Century, with the gradual beginning of industrialization, and apart from the advent of electricity, water gets new outlines, market included, and the hydroelectricity starts to stand out, then.

As approached before, the structural situation of the infrastructure and development of the country provided the planning of the hydric resources management to generate electricity with a strategic bias. Within this context, with the promulgation of the 1934 Código de Aguas, establishing the monopoly of the State by the Union Sovereign upon all natural resources of the national territory, the institution of intervener, inductor, and impeller character of the projects for resource exploration was elaborated. A sturdy electric system was built up until the beginning of the 1980s, based on hydroelectricity, with reservoirs and long interconnected transmissions.

However, the reforms that culminated in 2004, with the national electric sector emerging and transformed by a series of changes that altered the eminently-state character, molded into a public-private mix. The control of some of the hydroelectric plants fundamental for the system is passed on to the private initi- 
ative by several models: concession/share ${ }^{10}$.

Therefore, saturation of the generating capacity expansion model is observed, and which is in crisis, once big reservoirs will be no longer built - at least they are not expected to be, and that's what is understood in the decennial plan presented by the institutions. Thus, it is necessary that the electric generation expansion should be done upon using and exploring other resource sources, among which, the so-called the new renewables, specially Eolic and solar.

However, practical problems and difficulties connected to the intermittence and insufficiency of these sources are presented as challenges to be overcome through rationality and planning.

Seeking to solve the impasse that is somewhat civilizing, as it is more structural than circumstantial, the possibility of integration among different sources of resources to compensate and amortize the imposed difficulties is proposed. The interaction of solar and Eolic systems with others, based on water, permits the amortization of demands for new renewable sources. There is a complementary factor between the regimes of rain and wind and the daily availability of the Sun. Moreover, it is possible to work out by combining the sugar cane crops, in a system of intermittent renewables that should present bigger predictability and, thus, safety.

For such, massive investments in transmission are necessary, inasmuch as the whole complementarity among sources of resources that is expected to be used will be only feasible if they are connected to the National Interconnected System. Still, legal adequacies, especially for distributions, would be requirements to carry out projects, with incentives to build up markets, either upon induction of attractiveness, or the prominence of the State itself.

Thus, the prominence and importance of an adequate analytical consideration of the political dimension about the issue becomes evident. Alike the possession, the use and exploration of the water showed to be a political impasse in the beginning of the XX Century. In a similar way, the models for use and exploration of new sources are subjects of social and political disputes.

As this dispute situation is a reflex of the diversity of interests of the several agents involved and interested, for the Integrated Planning of Resources the consideration of the Political Dimension as of this historic perspective upon the question is just what permits the identification of what was called impasse. The perception that the construction of new water dams will no longer be possible, as well as whether the implementation of thermonuclear energy projects will be possible or not, for example, is provided pursuant to the consolidation of the analytical perception of the Political Dimension.

\section{Conclusions}

Considering the development of the work of analysis of the Political Dimension

${ }^{10}$ It is important to highlight that, in both cases, the national sovereign is not being abandoned, ultimately. 
of the electric sector planning, from the perspective of the appreciation of the historic narrative, specifically in the case of Brazil, it was possible to observe how the evolution dynamics of the governing and institutional structures of decision-making and implementation of projects was focused on the dispute between statist and privatizing models.

In the long run of the disputes, the possibility of investments and the structuration of pricing remained constantly as the neuralgic point, and this is truly the impasse that surrounds the sector.

In an objective manner, the evolution of the criteria and influent vectors in the conformation and progress of energetic projects, with the real growth of the consideration about the environmental impacts, as costs not only ecologic, but factually economic, represented a transformation in the traditional possibilities of expansion of generation of electricity.

Likewise, the social impacts of the developments gained economic relevance, too, while costs, inasmuch as they began to entail difficulties that were not formerly significant due to the negligence even conceptual with which these impacts were worked on and taken into consideration.

Therefore, the progression of the evolution of the generation of electricity in Brazil, practically neglecting in an official manner the transformations of the societal paradigms, ended up in a non-planned or non-forecast alteration of the national matrix. The structural model based on hydroelectricity, having thermal generation as element of further safety, was little by little depreciated and exhausted towards a truly hydrothermal model of electric matrix, with thermos-generating plants, appearing no longer as a safety support but as the structural base of the whole national generating plant.

With the growth of the energetic demand, and, more specifically, electric, the expansion of the supply gained politically innovative outlines in the mid-term, with the management of the demand becoming the focus of attention not formerly regarded. At first turned exclusively towards the bias of efficiency and the rational use of energy, that is, towards the consume action itself, the perspective of analysis if the demand world evolved into troublesome criticism about the reasons intrinsic in the demand and energetic demand.

The PIR-Integrated Planning of Resources, while strategic planning tool and instrument, proposes to carry out the approach of the supply and demand, in a systematic manner and procedurally integrated, recognizing, thus, the character eminently systemic of the societal operating structures while they form their own manner of production, circulations, and consume.

Including the analysis of the Political Dimension within its theoretical and conceptual scope represents the search for adequacy and accuracy concerning diagnoses of situations and problems as well as anticipation of trends of difficulties and impracticability, in economic, social, or environmental costs, represented simultaneously in political costs. Moreover, the inclusion of the Political Dimension is an element of repositioning the planning idea itself, no longer purely 
technical, but above all abstract and subjective while social choice in time, and, therefore, political.

As said before, and having in view that planning implies decision-making actions, which are in fact choices in time, the adoption of the historic perspective as the basilar path for the analysis of the Political Dimension emerges as an inexorable option, from the theoretical viewpoint.

However, its adequacy within the context of the other dimensions to be considered is not a simple but complex task. The valuation and quantification of its vectors so as to be able to be included in a language compatible with the rest of the considerations was developed in a case study (Galvão, Martim; 2015). Shown to be circumstantially satisfactory, the final insufficiency must be pointed out, concerning the most important objective, which is just that of allowing the transpositions of the discourse towards a universe even monetarized, of comparative considerations, so as that the preconized planning results in an ambient of development and implementation of projects that is in conformity with the expectations of practicability and assurance of premises formerly established.

Therefore, it is imperative that one should observe how the present work approached the strategic planning while elaboration of what is public. This means that the Public Power in the figure of the National State was object of higher appreciation, having its institutions playing the central role in the approach and analysis of the question.

Conclusively, the analysis of the political dimension of the electric sector planning in Brazil points towards the impracticability of the continuation of the current hydrothermal model, with the necessary expansion of the integration among intermittent sources, in special Eolic, solar, hydric, and thermal based on biofuels and natural gases. Also, the high pricing of the cost of electricity and the perception that there is no satisfactory solution in all aspects can and must be presented as conclusions achieved.

\section{References}

[1] Udaeta, M.E.M. (1997) Planejamento Integrado de Recursos energéticos-PIR—para o setor elétrico: Pensando o Desenvolvimento sustentável, 1997. Tese (Doutorado)_Escola Politécnica da Universidade de São Paulo, Universidade de São Paulo, São Paulo.

[2] Bernal, J.L.O., Udaeta, M.E.M., Rigolin, P.H.C. and Gimenes, A.L.V. (2017) A Model of Energy Planning Considering Both Energy Supply and Demand as Resources for Sustainable Development. In: Gonzalez, J., Ed., Energy Planning-Approaches and Assessment, Nova Science Publishers, Nova Iorque, Cap. 1, 1-33.

[3] Mujica, J. (2013) Discurso na 68ª Assembleia Geral das Nações Unidas (ONU). https://gadebate.un.org/sites/default/files/gastatements/68/UY_es.pdf

[4] Medeiros, R.A. (1993) O capital privado na reestruturação do setor elétrico brasileiro. In. História e Energia, n. 6, São Paulo, Eletropaulo: Departamento de Patrimônio Histórico, 1996. Tese de mestrado apresentada à UFRJ, Rio de Janeiro.

[5] CÓDIGO DE ÁGUAS. Código de Águas, 1934. Departamento Nacional de Água e Energia Elétrica. Ministério das Minas e Energia. Brasília: DNAEE, 1980. 
http://www2.camara.leg.br/legin/fed/decret/1930-1939/decreto-24643-10-julho-193 4-498122-publicacaooriginal-1-pe.html

[6] Vargas, G. (1954) Última Carta ao Povo Brasileiro. http://www.culturatura.com.br/dochist/Carta\%20Testamento\%20-\%20Getlio\%20V argas.pdf 


\section{Appendix: Complementary Bibliography}

ANEEL (Agência Nacional de Energia Elétrica). Brasília, Brasil.

$<$ http://www.aneel.gov.br/>.

BANCO MUNDIAL. World development report 1997. Oxford University Press, set.

BEN 2004. Balanço Energético Nacional, Ministério de Minas e Energia, Brasília, ano base 2003.

BEN 2014; EPE/MME. Relatório Síntese, ano base 2013.

BENHABIB, S. Critique, norm and utopia. A study of the foundations of critical theory. Nova York: Columbia University Press, 1986.

S. Sobre um modelo deliberativo de racionalidade democrática. Nova York: Columbia University Press, 2007. In: WERLE, D. L.; MELO, R. S. (Orgs.). Democracia Deliberativa. Esfera Pública, 2007 p.47-79.

BIAGUE, M. F. Modelagem da carteira dos recursos energéticos para $o$ Planejamento Integrado dos Recursos energéticos. São Paulo, 2010; Tese (Doutorado)—Escola Politécnica da Universidade de São Paulo. Departamento de Engenharia de Energia e Automação Elétricas, 2010.

BRASIL. Constituição (1988). Constituição da República Federativa do Brasil. Brasília, DF: Senado, 1988.

BRUNDTLAND. Our Common Future. Relatório da Comissão Mundial Sobre Meio Ambiente e Desenvolvimento da ONU, 1987.

CNPE (conselho nacional de política energética).

$<$ http://www.mme.gov.br/mme/menu/conselhos_comite/cnpe.html $>$.

ELETROBRAS. <http://www.eletrobras.com/ >.

EPE (Empresa de Pesquisas Energéticas). <http://www.epe.gov.br/>.

FAPESP 03/06441-7. Novos instrumentos de planejamento energético regional visando o desenvolvimento sustentável, 2009.

FERRI, M. G.; MOTOYAMA, S. (Orgs.). História das ciências no Brasil. São Paulo: EDUSP, EPU, CNPQ, 1979, 1981.

FOUCAULT, M. Microfísica do poder. Tradução: Roberto Machado. Rio de Janeiro: Graal, 1979.

FRASER, N. Justice interruptus. Nova York: Routledge, 1997.

FURTADO, C. Formação econômica do Brasil. São Paulo: Nacional, 1977.

GALVÃO, L.C.R.; GRIMONI, J.A.B.; UDAETA, M.E.M. (Orgs.). Iniciação a conceitos de sistemas energéticos para o desenvolvimento limpo. São Paulo: Editora da Universidade de São Paulo, 2004.

GOLDEMBERG, J.; LUCON, O. Energia, meio ambiente e desenvolvimento. São Paulo, Edusp, 2008.

HARDIN, G. The Tragedy of the Commons. Science, 1968.

HISTÓRIA E ENERGIA. Estatização $x$ Privatização. São Paulo, Eletropaulo: Departamento de Patrimônio Histórico, 1997. Conferências e Debates, vários autores.

LIMA, J. L. Políticas de governo e desenvolvimento do setor de energia 
elétrica. Rio de Janeiro; Memória da Eletricidade, 1995.

MME (Ministério de Minas e Energia). <http://www.mme.gov.br/mme/>.

MOTOYAMA, S. (Org.). Tecnologia e industrialização no Brasil. São Paulo:

Unesp, 1994.

NAE (Núcleo de Assuntos Estratégicos-da Presidência da República).

ONS (Operador Nacional do Sistema). <http://www.ons.org.br/home/>.

PETROBRAS. < http://www.petrobras.com.br/pt/>.

PORTAL DA CÂMARA DOS DEPUTADOS. Câmara Federal.

$<\underline{\text { http://www2.camara.leg.br }>\text {. }}$

REIS, A.G. $A$ arquitetura da integração energética sul-americana, a participação brasileira e geoenergia humana. 2014. Dissertação (Mestrado)-Escola Politécnica da Universidade de São Paulo. Departamento de Engenharia de Energia e Automação Elétricas, 2014.

SAUER, I. A reconstrução do setor elétrico brasileiro. Campo Grande: Ed. UFMS; São Paulo: Paz e Terra, 2003. Vários autores.

SAUER, I. Caminhando e buscando: Contribuições a um modelo de organização para o setor elétrico brasileiro \& Organização da produção e apropriação da energia na sociedade: Reflexões epistemológicas. Texto de sistematização crítica da obra do candidato e tese, apresentados ao Instituto de Eletrotécnica e Energia para a obtenção do título de Livre Docente na área de Energia. São Paulo, 2004.

SEEDS. <http://seeds.usp.br/cursos/login/index.php>.

SENADO FEDERAL. <http://www.senado.gov.br $>$.

SILVEIRA, A. M. A relação entre os preços de açúcar nos mercados doméstico e internacional. 2004. Dissertação (Mestrado em Ciências)—Escola Superior de Agricultura Luiz de Queiroz, Universidade de São Paulo, Piracicaba, 2004.

UDAETA, M.E.M. Planejamento Integrado de Recursos energéticos-PIR—para o setor elétrico: Pensando o Desenvolvimento sustentável, 1997. Tese (Doutorado)_Escola Politécnica da Universidade de São Paulo, Universidade de São Paulo, São Paulo, 1997.

ÚNICA (União da Indústria de Cana-de-Açúcar). <www.unica.com.br $>$.

VARGAS, M. História da ciência e da tecnologia no Brasil: uma súmula. São Paulo: Humanitas/FFLCH/USP: Centro Interunidade de História da Ciência, 2001.

VIEIRA J.P.; CASTRO, N.J.; RECH, H.; BURANI, G.F: Energia elétrica: Uma concepção estratégica.

WEBER, M. A ética protestante e o "espírito" do capitalismo. (1864-1920). São Paulo: Companhia das Letras, 2004.

YOUNG, I. Inclusion and democracy. Oxford: Oxford University Press, 2000.

YOUNG, I. Justice and the politics of difference. Princeton: Princeton University Press, 1990. 